\title{
PENGAJARAN BAHASA ARAB MENGGUNAKAN MEDIA GAMBAR BERGERAK UNTUK MENINGKATKAN PENGUASAAN KOSAKATA
}

\author{
Mariyatul Qibtiyah, Walfajri \\ Institut Agama Islam Negeri Metro \\ email: mariyatulqibtiyah385@gmail.com
}

\begin{abstract}
This study aimed to analyze the process of teaching Arabic using moving picture media and the level of vocabulary mastery in Islamic Junior High School. This research method was quantitative with an experimental approach. The research was conducted at Islamic Junior High School Darul Amal Metro, involving 30 students of grade VIII as the sample. The data collection method used a test. The test method was aimed at students to get vocabulary mastery data. The data analysis technique used the T-test to determine the level of vocabulary mastery after using moving picture media. The results showed that the learning process by using moving picture media had been able to increase students' learning activities and enthusiasm. The spirit of learning characterized by a high concentration during the learning process, encouraging students to understand the lesson easily. The high of learning concentration caused by the characteristics of the moving picture media varied and corresponded with students' progress. The success of using moving picture media was supported by the teacher's ability to use media. The results of statistical analysis showed that the application of moving picture media in learning Arabic had a significant effect on students' vocabulary mastery.
\end{abstract}

Keywords: Arabic Teaching; Moving Picture Media; Vocabulary Mastery.

\begin{abstract}
Abstrak
Studi ini bertujuan untuk menganalisis proses pengajaran bahasa Arab menggunakan media gambar bergerak dan tingkat penguasaan kosakata di Madrasah Tsanawiyah. Metode penelitian ini adalah kuantitatif dengan pendekatan eksperimen. Penelitian ini dilakukan di MTs Darul A'mal Metro, sampel penelitian ini adalah siswa kelas VIII berjumlah 30 orang. Metode pengumpulan data menggunakan tes. Metode tes ditujukan kepada siswa untuk mendapatkan data penguasaan kosakata. Teknik analisis data dilakukan dengan uji T untuk mengetahui tingkat penguasaan kosa kata setelah penggunaan media gambar bergerak. Hasil penelitian menunjukkan bahwa proses pembelajaran
\end{abstract}


dengan menggunakan media gambar bergerak telah mampu meningkatkan aktivitas dan semangat belajar siswa. Semangat belajar yang ditandai dengan konsentrasi yang tinggi selama proses pembelajaran mendorong siswa mudah memahami pelajaran. Hal tersebut disebabkan oleh karakteristik media gambar bergerak yang variatif dan sesuai dengan perkembangan siswa. Keberhasilan penggunaan media gambar bergerak didukung oleh kemampuan guru dalam pemanfaatan media. Hasil analisis statistik menunjukkan bahwa penerapan media gambar bergerak dalam pembelajaran bahasa Arab berpengaruh signifikan terhadap penguasaan kosakata siswa.

Kata Kunci: Pengajaran Bahasa Arab; Media Gambar Bergerak; Penguasaan Kosakata.

\section{A. Pendahuluan}

Pengajaran bahasa Arab pada siswa Madrasah Tsanawiyah dihadapkan pada berbagai tantangan dan kesulitan dan problem yang berujung tidak tercapainya tujuan pembelajaran yang di inginkan terutama pada aspek penguasaan kosakata. Beberapa kesulitan yang dialami siswa pada aspek penguasaan kosakata di antaranya adalah siswa tidak menguasai kosakata yang digunakan dalam komunikasi sehari-hari, siswa sulit menggunakan kosakata dalam struktur kalimat dan siswa tidak memahami makna kosakata di dalam struktur baca. Kesulitan-kesulitan ini bersumber pada media belajar yang tidak relevan dan sarana prasarana yang tidak memadai yang menjadikan pembelajaran monoton dan membosankan. Nurmadiah menjelaskan di antara kesulitan belajar yang dialami siswa dalam menerima materi pelajaran adalah karena proses pembelajaran tidak didukung oleh media yang menyenangkan dan relevan dengan materi. Hal ini disebabkan karena peran media dalam pembelajaran adalah meningkatkan kecepatan belajar, mengurangi beban guru dalam menyiapkan informasi dan membuat aktivitas guru lebih terarah untuk meningkatkan semangat dan prestasi belajar. ${ }^{1}$ Hal ini juga dijelaskan Tafonao bahwa hasil belajar tidak bisa dicapai tanpa peran media dalam proses pembelajaran. Tanpa penggunaan media, guru akan mengalami kesulitan-kesulitan dalam menjelaskan materi, selain itu siswa akan mengalami kesulitan dalam menerima materi. Hal ini disebabkan karena media berperan untuk memotivasi siswa agar dapat berinteraksi satu sama lain dari berbagai sumber belajar yang sudah ada. ${ }^{2}$

Kesulitan-kesulitan yang dialami pada siswa di dalam pembelajaran bahasa Arab di Madrasah Tsanawiyah diidentifikasi pada dua problem utama pertama, yaitu: kesulitan yang bersumber pada penggunaan media yang tidak

\footnotetext{
${ }^{1}$ Nurmadiah, "Media Pendidikan," Al-Afkar : Jurnal Keislaman \& Peradaban 5, no. 1 (2016): 43-62, https://doi.org/10.28944/afkar.v5i1.109.

${ }^{2}$ Talizaro Tafonao, "Peranan Media Pembelajaran Dalam Meningkatkan Minat Belajar Mahasiswa," Jurnal Komunikasi Pendidikan 2, no. 2 (2018): 103, https://doi.org/10.32585/jkp.v2i2.113.
} 
sejalan dengan perkembangan siswa di samping tidak sesuai dengan materi. Yang kedua, kesulitan bersumber dari dukungan-dukungan sarana prasarana yang tidak maksimal sehingga guru sulit untuk mengembangkan media pembelajaran. Selama ini penelitian tentang bahasa Arab di Madrasah Tsanawiyah cenderung menganalisis dua isu utama. Pertama, penelitian yang menganalisis tentang pengajaran kosakata dan strategi pembelajarannya. Kedua, kemampuan penguasaan kosakata siswa yang baik dengan menggunakan media yang sesuai. ${ }^{3}$

Penelitian ini melengkapi penelitian kekurangan terdahulu yang cenderung mengabaikan keterlibatan siswa secara aktif dalam proses penguasaan kosakata. Tidak keterlibatan siswa dalam hal tersebut dapat menyebabkan rendahnya tingkat partisipasi siswa dalam proses pembelajaran. Penelitian ini akan menggambarkan penguasaan kosakata dalam pengajaran. Sejalan dengan tujuan ini pertanyaan dirumuskan: (1) bagaimana proses pengajaran bahasa Arab di Madrasah Tsanawiyah menggunakan media gambar bergerak. (2) bagaimana tingkat penguasaan kosakata di Madrasah Tsanawiyah. Jawaban dari pertanyaan ini dapat berkontribusi dalam menyelesaikan problema-problema yang dialami siswa dalam pembelajaran bahasa Arab.

Penelitian ini didasari pada argumentasi pertama, penggunaan media gambar bergerak dapat meningkatkan penguasaan kosakata bahasa Arab. Media ini tentunya akan sangat membantu siswa dalam proses pembelajaran dengan baik demi tercapainya tujuan pembelajaran pada tingkat kemampuan dalam menguasai kosakata yang dimiliki oleh siswa. Kedua, keberhasilan pengajaran bahasa Arab dengan menggunakan media gambar bergerak tidak akan berhasil tanpa didukung dengan ketersediaan sarana dan prasarana. Dapat dipahami bahwa pentingnya sarana dan prasarana dalam pembelajaran merupakan bagian dari upaya mencapai tujuan pembelajaran. Pada proses pembelajaran keberadaan sarana dan prasarana sangat dibutuhkan dan akan mengalami kesulitan jika tanpa adanya sarana dan prasarana.

\section{B. Studi Literatur}

\section{Konseptual Pengajaran Kosakata}

Secara tradisional, kebanyakan kosakata hanya bersifat insidental, maksudnya dilakukan hanya pada waktu tertentu saja, tidak secara tetap atau rutin dan terbatas untuk mempresentasikan item baru ketika membaca teks, atau kadang-kadang ketika mendengarkan suatu berita atau bacaan lainnya dan pengajaran kosakata ini tidak langsung

\footnotetext{
${ }^{3}$ Gaguk Rudianto dan Yessie Aldriani, "Pengajaran Kosa Kata Bagi Mahasiswa EFL Dengan Menggunakan Game," BASIS: Jurnal Bahasa Dan Sastra Inggris 5, no. 2 (2018): 5362, https://doi.org/10.33884/basisupb.v5i2.770.
} 
mengklaim bahwa perluasan kosakata akan terjadi melalui latihan keterampilan bahasa lain, yang sudah terbukti tidak hanya dengan perluasan kosakata saja. ${ }^{4}$ Pengajaran kosakata mungkin bermasalah karena banyak guru tidak yakin tentang praktek yang baik dalam pengajaran kosakata dan terkadang para guru tidak mengetahui bagian mana penekanan instruksional pembelajaran harus diberikan dan para guru setuju bahwa hampir tidak mungkin untuk belajar bahasa tanpa menguasai kata-kata bahkan komunikasi antar manusia didasarkan pada kosakata dan dalam belajar bahasa para siswa menyetujui tentang hal tersebut dan kosakata merupakan faktor utama dalam pembelajaran. ${ }^{5}$

Dalam kamus besar bahasa Indonesia kosakata diberi nama perbendaharaan kata, yang berarti semua kata terdapat dalam satu bahasa. ${ }^{6}$ Dengan paparan di atas, dapat diambil kesimpulan bahwa kosakata adalah keseluruhan kata yang dimiliki suatu bahasa, yang dimiliki seseorang ataupun juga seorang pembicara dan kosakata juga memiliki fungsi yang sangat penting dalam keterampilan berbahasa dan semakin banyak kosakata yang dimiliki maka semakin terampil pula dalam berbahasa. ${ }^{7}$ Pengajaran kosakata pada umumnya dilakukan melalui pengajaran kosakata dan maknanya melalui penggunaannya dalam konteks, suatu proses analisis terhadap kosakata ketika makna bagian kata diajarkan, pengajaran langsung terhadap makna kata dari daftar kata.

Teknik pengajaran kosakata yaitu: Guru mengucapkan kosakata dan siswa menirukan kembali, dengan menggunakan tanda baca yang lengkap guru menulis kosakata di papan tulis, kemudian memberikan arti kata kepada siswa dengan tidak menggunakan terjemah, dan supaya lebih jelas guru membuat satu kalimat atau lebih dari kosakata tersebut, guru meminta siswa untuk mengulang salah satu kalimat, setelah itu memperhatikan cara siswa menulis kata, guru menulis arti kata di papan,

\footnotetext{
${ }^{4}$ Halimi Zuhdy, "Teknik Pengajaran Kosa Kata Bahasa Arab" (Workshop Peningkatan Pembelajaran Bahasa Arab Bagi Pengajar Pondok Pesantren, Fakultas Humaniora UIN Maulana Malik Ibrahim Malang, 28 Oktober 2017), http://repository.uinmalang.ac.id/2138/.

${ }^{5}$ Rudianto dan Aldriani, “Pengajaran Kosa Kata Bagi Mahasiswa EFL Dengan Menggunakan Game."

${ }^{6}$ Azisah Ardiyanti, Irianti Bandu, dan Moses Usman, "Pembelajaran Kosakata Bahasa Prancis Dengan Media Flashcard (Studi Kasus Pada Mahasiswa Sastra Prancis)," Jurnal IImu Budaya 6, no. 1 (2018), https://doi.org/10.34050/jib.v6i1.4327.

${ }^{7}$ Nurliya Febrisma, "Upaya Meningkatkan Kosa Kata Melalui Metode Bermain Peran Pada Anak Tunagrahita Ringan (PTK Kelas DV Di SLB Kartini Batam)," Jurnal Penelitian Pendidikan Khusus 2, no. 2 (2013), http://ejournal.unp.ac.id/index.php/jupekhu/article/view/1150.
} 
guru meminta siswa untuk membaca kosakata baru yang ada di papan beserta artinya. ${ }^{8}$

Hakikat pengajaran kosakata menjadi penelitian kosakata yang tepat, khususnya dalam rangka penyusunan materi pelajaran, merupakan faktor yang sangat dipertimbangkan kesahihannya. Sehubungan dengan itu, teks pelajaran bahasa yang disusun berdasarkan frekuensi kosakata untuk lebih bisa membina kekayaan kosakata yang diharapkan akan memberikan kemungkinan pembelajaran bahasa yang cepat, lebih mudah, dengan penguasaan kosakata yang lebih sesuai dengan tujuan pembelajaran yang ingin dicapai.

Dengan adanya penguasaan bahasa yang memiliki peran sebagai alat komunikasi dan berinteraksi dengan terampil, maka seorang yang belajar bahasa harus benar-benar menguasai kosakata karena hal tersebut akan sangat membantu siswa belajar bahasa Arab. ${ }^{9}$ Tujuan umum pengajaran kosakata bahasa Arab adalah sebagai berikut: Memperkenalkan kosakata yang baru kepada siswa memahami arti kosakata, baik secara denotasi yaitu menunjukkan makna yang sebenarnya maupun ketika digunakan dalam konteks kalimat tertentu. ${ }^{10}$

\section{Media Gambar Bergerak}

Secara umum media merupakan perantara/ pengantar dari pengirim kepada penerima pesanan, dalam sebuah proses belajar mengajar adanya media sangat penting digunakan untuk menyampaikan materi pembelajaran. Media merupakan alat yang digunakan sebagai penyampaian isi materi pengajaran, dalam hal ini buku/ modul, tape recorder, kaset, video recorder, kamera video, televisi, radio, film, slide, foto, gambar bergerak dan komputer merupakan media pembelajaran dan bentuk dari komunikasi baik itu yang tercetak maupun audio visual dengan peralatannya, di antara media pembelajaran media gambar bergerak juga yang paling umum dipakai, apalagi jika gambar dibuat tersusun dan disajikan dengan baik, hal itu akan lebih menambah

\footnotetext{
${ }^{8}$ Khoirotun Ni'mah, “Korelasi Penguasaan Kosakata Bahasa Arab Dengan Kemampuan Berpidato Bahasa Arab Mahasiswa PBA UNISDA Lamongan," DAR EL-ILMI : Jurnal Studi Keagamaan, Pendidikan Dan Humaniora 4, no. 1 (2017): 121, http://www.ejurnal.unisda.ac.id/index.php/dar/article/view/689.

${ }^{9}$ Sitti Hasnah, “Pembelajaran Kosakata (Mufradat) Bahasa Arab Melalui Media Gambar Untuk Meningkatkan Minat Belajar Mahasiswa Pada Jurusan PAI Fakultas Tarbiyah IAIN Palu," Istiqra: Jurnal Hasil Penelitian 3, no. 1 (2015): 197-225, https://jurnal.iainpalu.ac.id/index.php/ist/article/view/217.

${ }^{10}$ Widi Astuti, "Berbagai Strategi Pembelajaran Kosa Kat Bahasa Arab," Journal AlManar 5, no. 2 (2016), https://journal.staimsyk.ac.id/index.php/almanar/article/view/38.
} 
semangat siswa dalam mengikuti proses belajar mengajar. ${ }^{11}$ Ketika media ini dikaitkan dengan pembelajaran bahasa Arab, maka ia bermakna segala bentuk komunikasi beserta peralatan yang digunakan oleh guru bahasa Arab di tengah-tengah kegiatan pembelajaran bahasa Arab untuk memudahkan mencapai tujuan pembelajaran. ${ }^{12}$

Gambar adalah segala sesuatu yang diwujudkan secara visual dalam bentuk dua dimensi sebagai curahan perasaan atau pikiran. ${ }^{13}$ Gambar bergerak atau animasi termasuk ke dalam media motion-visual, yakni media yang berupa gambar objek bergerak tetapi tidak dengan suara, seperti film bisu yang bergerak. ${ }^{14}$ Penggunaan media gambar bergerak dalam pembelajaran sangat membantu dalam meningkatkan proses pengajaran khususnya bahasa Arab dan selain itu penggunaan media pembelajaran berupa gambar bergerak dapat meningkatkan daya pikat, serta motivasi siswa dalam belajar bahasa Arab. ${ }^{15}$

\section{Metode Penelitian}

Penelitian ini menganalisis media gambar bergerak dalam meningkatkan penguasaan kosakata. Tempat penelitian ini adalah MTs Darul A'mal Metro. Pemilihan lokasi penelitian didasarkan atas pertimbangan bahwa sekolah ini memiliki keunggulan karena guru qualified, dan fasilitasnya lengkap. Penelitian ini dirancang guna memecahkan masalah dalam bidang pengajaran bahasa Arab. Penelitian ini bersifat penelitian eksperimen untuk menguji tingkat penguasaan kosakata setelah diterapkannya media gambar bergerak. Sampel penelitian ini adalah siswa kelas VIII berjumlah 30 dengan desain post test pre test. Selanjutnya dalam tindakan eksperimen disebut treatment, dan diartikan sebagai semua tindakan, semua variasi atau pemberian kondisi yang akan diketahui pengaruhnya.

\footnotetext{
${ }^{11}$ Yuswanti Yuswanti, “Pengunaan Media Gambar Untuk Meningkatkan Hasil Belajar Siswa Pada Pembelajaran IPS Di Kelas IV SD PT. Lestari Tani Teladan (LTT) Kabupaten Donggala," Jurnal Kreatif Online 3, no. 4 (2014), http://jurnal.untad.ac.id/jurnal/index.php/JKTO/article/view/3077.

12 Hilmi Hilmi, "Efektivitas Penggunaan Media Gambar Dalam Pembelajaran Bahasa Arab," Lantanida Journal 4, no. 2 (2017): 128, https://doi.org/10.22373/lj.v4i2.1885.

${ }^{13}$ Isma Afriyanti, Fadillah, dan Sukmawati, “Penggunaan Media Gambar Untuk Meningkatkan Aktivitas Dan Hasil Belajar Siswa Pada Mata Pelajaran Ilmu Pengetahuan Alam Di Sekolah Dasar Negeri," Jurnal Pendidikan Dan Pembelajaran Khatulistiwa 2, no. 2 (2013), http://jurnal.untan.ac.id/index.php/jpdpb/article/view/1049.

${ }^{14}$ Yuswanti, "Pengunaan Media Gambar Untuk Meningkatkan Hasil Belajar Siswa Pada Pembelajaran IPS Di Kelas IV SD PT. Lestari Tani Teladan (LTT) Kabupaten Donggala."

${ }^{15}$ Kadek Sukiyasa dan Sukoco Sukoco, "Pengaruh Media Animasi Terhadap Hasil Belajar Dan Motivasi Belajar Siswa Materi Sistem Kelistrikan Otomotif," Jurnal Pendidikan Vokasi 3, no. 1 (2013), https://doi.org/10.21831/jpv.v3i1.1588.
} 
Kelas eksperimen akan diajar dengan media gambar bergerak. sebelum pelaksanaan eksperimen, kelas eksperimen akan dilaksanakan pre test untuk mengetahui tingkat penguasaan kosakata sebelum diberi perlakuan dengan menerapkan media gambar bergerak. Setelah pelaksanaan eksperimen dilakukan post test untuk mengetahui tingkat penguasaan kosakata setelah diberi perlakuan media gambar bergerak.

Adapun teknik pengumpulan data yang dilaksanakan dengan menggunakan observasi dan menggunakan tes. Dengan observasi dapat melengkapi format atau blangko pengamatan sebagai instrumen pertimbangan. kemudian format yang disusun berisi tentang kejadian atau tingkah laku yang digambarkan. Diperoleh suatu petunjuk bahwa mencatat data observasi dengan mengadakan pertimbangan kemudian mengadakan penilaian. Seperti memperhatikan reaksi siswa dengan menggunakan media gambar bergerak untuk mengetahui tingkat penguasaan kosakata siswa dan mencatat reaksi tersebut serta menilai apakah masih kurang atau sudah sesuai dengan apa yang dikehendaki. Sedangkan Tes dilakukan untuk mengetahui tingkat penguasaan kosakata baik sebelum dan setelah diberi perlakuan. Dari aspek yang diukur maka pengumpulan data dilakukan dengan model tes kosakata yang terdiri dari tes kemampuan penguasaan kosakata.

Sedangkan teknis analisis data dilakukan dengan uji prasyarat yaitu homogenitas dan uji normalitas yang kemudian dilanjutkan dengan uji $\mathrm{T}$ untuk mengetahui tingkat penguasaan kosakata setelah penggunaan media gambar bergerak. Penelitian ini menggunakan perhitungan secara numerik dan analisis dilakukan dengan menggunakan statistik, yaitu dengan cara mengetahui hasil dari penelitian yang dilakukan. Analisis data dapat dilakukan dengan bantuan program SPSS. Dan sebagai aktivitas yang dilakukan untuk mengubah data penelitian menjadi informasi yang baru dan dapat digunakan untuk membuat kesimpulan. Kesimpulan analisis data bisa diperoleh dari sampel yang didasarkan pada dugaan atau hipotesis.

\section{Hasil Penelitian}

\section{Proses Penggunaan Media Gambar Bergerak}

Hasil analisis terhadap proses penerapan media gambar bergerak dalam pembelajaran bahasa Arab untuk meningkatkan penguasaan kosakata dideskripsikan dalam beberapa langkah. Pelajaran dimulai dengan penyampaian materi pelajaran. Serta diiringi dengan melakukan apersepsi terhadap penguasaan materi yang lalu. Di samping itu juga memberikan motivasi belajar terhadap siswa. Guru juga membuat formasi tata letak meja, kursi, dan perabot kelas yang lain sesuai dengan kesepakatan kelas dan guru mengajak siswa belajar secara aktif, ketika siswa belajar dengan aktif berarti mereka yang mendominasi aktivitas pembelajaran. Selain guru menyiapkan suasana kelas dalam penerapan 
media gambar bergerak, guru juga mempersiapkan kesiapan mental siswa menerima pelajaran dengan media. Guru menyiapkan media berupa gambar animasi yang berisi poin-poin materi untuk mendukung penjelasan guru. Instrumen evaluasi juga telah disiapkan oleh guru sejak awal pembelajaran sebagai tolok ukur kemampuan pemahaman siswa dalam penguasaan kosakata setelah menggunakan media gambar bergerak.

Guru mengajar sesuai dengan panduan materi pelajaran yang ada pada perencanaan pembelajaran. Guru memberi acuan yang berkaitan dengan materi yang dipelajari. Acuan tersebut berupa penjelasan materi pokok dan uraian materi pelajaran. Guru menetapkan dan merumuskan tujuan pembelajaran secara jelas, konkret, dan fungsional. Sesuai panduan guru, siswa juga perlu melakukan pembagian kelompok belajar dan menjelaskan pengalaman belajar dengan menggunakan media gambar bergerak selama berada di kelas sesuai dengan rencana dan tahapan pembelajaran. Pada tatap muka yang bukan untuk diskusi juga digunakan guru untuk mengalihkan ke bahasa dengan penekanan dan penggunaan pola-pola kalimat dan pemaknaan kosakata dalam konteks kalimat. Kemudian Langkah pembelajaran Inti juga berisi tahapan sistematis yang dilalui siswa untuk dapat mendesain ilmu sesuai dengan skema masingmasing. Tahapan tersebut disusun sedemikian rupa agar siswa dapat menunjukkan perubahan perilaku pada tujuan pembelajaran dan indikator. Untuk memudahkan, kegiatan inti juga dilengkapi dengan Lembar Kerja Siswa (LKS) dan pemberian tugas yang diberikan oleh guru kepada seluruh siswa.

Setelah kegiatan inti dilakukan penutup merupakan kegiatan akhir pembelajaran. Guru menutup pelajaran tidak hanya sekedar mengakhiri pelajaran dengan salam, tetapi di sini guru juga melakukan penekanan/ penguatan terhadap apa yang telah diperoleh siswa selama mengikuti pembelajaran. Guru memberikan simpulan terhadap apa yang telah dipelajari kemudian mengarahkan siswa membuat rangkuman materi yang sudah disampaikan. Dalam kegiatan penutup juga dilakukan penilaian dan refleksi terhadap pembelajaran yang telah dilakukan. Dapat juga dengan memberikan tes tertulis atau tes lisan atau meminta siswa untuk mengulang kembali simpulan yang telah disusun atau dalam bentuk tanya jawab dengan mengambil kurang lebih $25 \%$ siswa sebagai sampelnya. Langkah-langkah pembelajaran dimungkinkan disusun dalam bentuk seluruh rangkaian kegiatan, sesuai dengan karakteristik model pembelajaran yang dipilih. Sehingga kegiatan pendahuluan/ awal, kegiatan inti, dan kegiatan penutup tidak harus ada dalam setiap pertemuan. 


\section{Tingkat Penguasaan Kosakata di Madrasah Tsanawiyah}

Penguasaan faktor kosakata merupakan faktor penting dalam proses pembelajaran bahasa Arab. Kemahiran berbahasa sangat ditentukan oleh penguasaan kosakata. Penguasaan kosakata ditandai dengan kemampuan siswa dalam menghafal kosakata dan juga mengetahui arti kosakata tersebut dan antusias siswa dalam belajar kosakata dan bisa menggunakan kosakata menjadikan kalimat sehingga bisa mengaplikasikan dalam bahasa sehari-hari. Pelaksanaan bahasa Arab dengan menerapkan media gambar bergerak mampu meningkatkan penguasaan kosakata secara signifikan. Data dari hasil tes rata-rata nilai penguasaan kosakata sebesar 85,2 nilai rata-rata ini berada pada rentang 84-92 yang berarti baik.

Proses pembelajaran bahasa Arab menggunakan media gambar bergerak mendorong siswa mampu memahami materi yang diajarkan guru secara baik yang kemudian meningkatkan kemampuan penguasaan kosakata yang ditandai dengan menguasai kosakata sehari-hari, mampu menggunakan kosakata dalam kalimat. Peningkatan kemampuan penguasaan kosakata pada siswa dikarenakan dalam penerapan media gambar bergerak ini sangat membantu siswa dalam proses pembelajaran. Dengan menggunakan media gambar bergerak siswa lebih senang dan tidak bosan dengan materi pelajaran yang diberikan. Karena pada dasarnya siswa lebih suka belajar dengan media gambar daripada tertulis.

Hasil analisis data tes pada siswa menunjukkan adanya peningkatan penguasaan kosakata secara signifikan. Peningkatan ini diketahui melalui uji T. Sebelum melakukan uji $\mathrm{T}$, data yang terkumpul dilakukan uji prasyarat yaitu uji normalitas dan uji homogenitas. Hasil uji normalitas dengan statistic uji Kolmogorof-Smirnov pada taraf signifikan $\alpha=5 \%=0,05$ diketahui nilai sig hitung masing-masing kelas secara berturut-turut 0,132, dan 0,089. (lihat tabel 1). Keputusan uji berdasarkan perhitungan ini nilai sig hitung $>$ dari $\alpha$ sehingga Ho diterima. Kesimpulan sampel penelitian berdistribusi normal dan dapat dilakukan uji lanjut.

\begin{tabular}{|c|c|c|c|c|c|c|c|}
\hline \multicolumn{8}{|c|}{ Tests of Normality } \\
\hline & \multirow[t]{2}{*}{ Kelas } & \multicolumn{3}{|c|}{ Kolmogorov-Smirnov ${ }^{\mathrm{a}}$} & \multicolumn{3}{|c|}{ Shapiro-Wilk } \\
\hline & & Statistic & Df & Sig. & Statistic & $\mathrm{df}$ & Sig. \\
\hline \multirow{2}{*}{ Hasil } & 1.00 & .131 & 30 & 0,132 & .904 & 30 & 0,132 \\
\hline & 2.00 & .158 & 30 & 0,089 & .953 & 30 & 0,089 \\
\hline
\end{tabular}

Selanjutnya dilakukan uji homogenitas dengan Levene Statistic dengan taraf signifikan $\alpha=5 \%=0,05$ nilai sig hitung sebesar $0,35>$ dari 
nilai $\alpha$. Bermakna Ho diterima. Hal ini menunjukkan bahwa varian sampel homogen. Lihat tabel 2.

\begin{tabular}{cccccc}
\multicolumn{4}{c}{ Tabel 2 - Hasil Uji Homogenitas Sampel } \\
\hline \multicolumn{4}{c}{ Test of Homogeneity of Variances } \\
\hline $\begin{array}{r}\text { Hasil } \\
\text { Levene Statistic }\end{array}$ & df1 & & df2 & & Sig. \\
17.134 & & 1 & & 58 & 0,35 \\
\hline
\end{tabular}

Berdasarkan uji prasyarat yang dilakukan sampel dalam penelitian ini berdistribusi normal dan variannya bersifat homogen artinya bahwa data hasil post test dapat dilakukan uji hipotesis dengan uji T. Hasil uji T pada taraf signifikan $\alpha=5 \%=0,05$ dengan kriteria jika sig hitung $>$ dari $\alpha$ maka Ho diterima. Dari table 3 diketahui pengaruh dari table diketahui nilai sig 0,00 dengan keputusan uji nilai sig hitung $<$ dari $\alpha$ sehingga Ho ditolak $\mathrm{H} \square$ diterima. Hasil uji $\mathrm{T}$ ini menunjukkan bahwa pembelajaran bahasa Arab menggunakan media gambar bergerak dapat meningkatkan kemampuan penguasaan kosakata pada siswa kelas VIII MTs Darul A'mal.

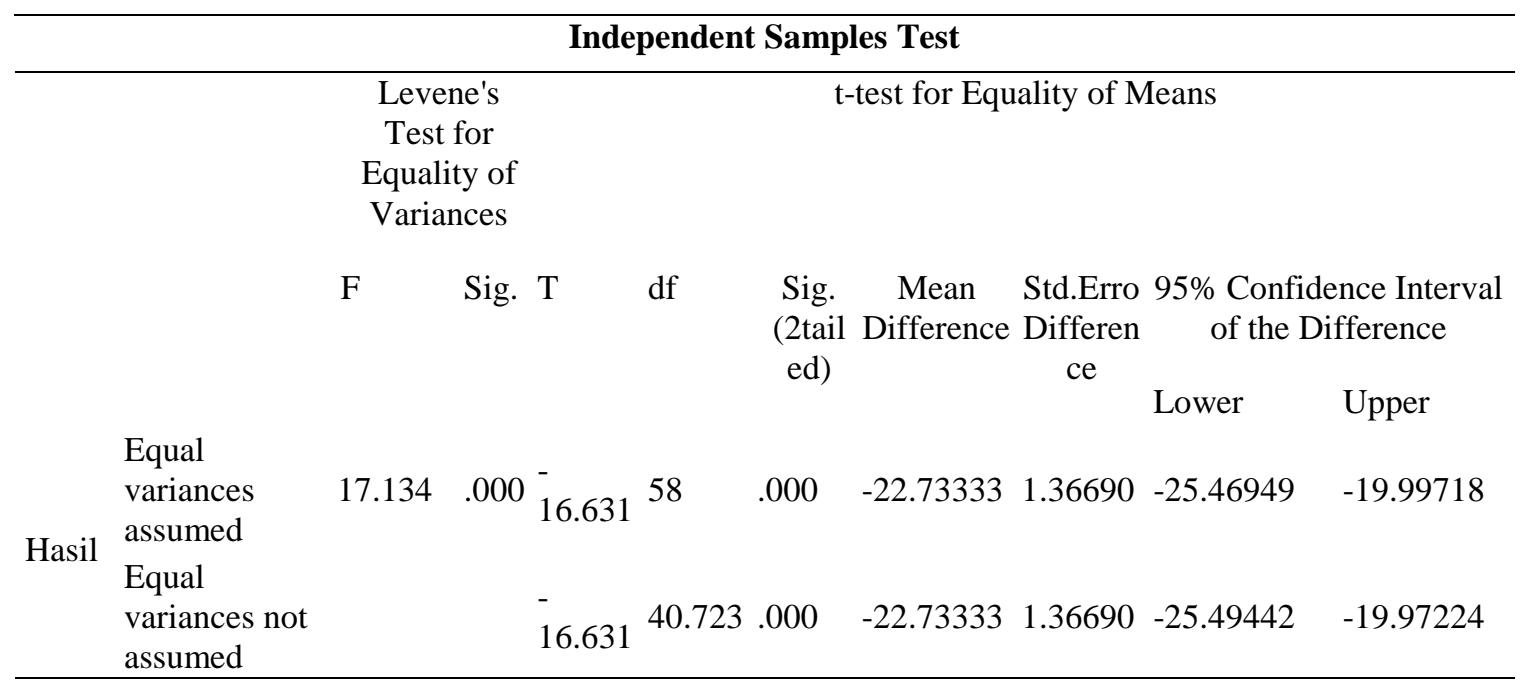

\section{E. Pembahasan}

Hasil penelitian menunjukkan bahwa penggunaan media gambar bergerak dapat meningkatkan penguasaan kosakata bahasa Arab. Media gambar yang digunakan guru dalam proses pembelajaran merupakan alternatif untuk meningkatkan hasil belajar siswa. Dalam penelitian ini lebih mengkhususkan penelitian terhadap pengaruh tingkat penguasaan kosakata siswa menggunakan media gambar bergerak. peneliti juga menggunakan referensi yang terdapat di dalam penelitian terdahulu. Hal tersebut dapat 
dibuktikan dengan hasil belajar siswa yang diperoleh dan peningkatan aktivitas siswa dan guru pada setiap pertemuan mengalami peningkatan dalam pembelajaran. Proses belajar yang paling meningkat adalah siswa aktif dalam kerja kelompok. Hal ini disebabkan karena siswa menyukai media gambar bergerak dan lebih mudah memahami materi yang diajarkan, siswa terbiasa hadir tepat waktu, memperhatikan ketika mengikuti pelajaran, mampu bersosialisasi dengan teman-temannya. Dengan penerapan media gambar bergerak siswa bisa langsung bertanya kepada guru karena dengan adanya media tersebut siswa bisa menemukan masalah yang diperoleh dan bisa bertanya kepada guru, termotivasi untuk belajar bekerja sama guna menyelesaikan suatu masalah. Hasil pelaksanaan pembelajaran kemampuan penguasaan kosakata di atas meningkat dikarenakan media yang telah digunakan.

Pelaksanaan pembelajaran menggunakan media gambar bergerak dilakukan guru dengan mensinergikan lingkungan kelas serta mengorganisir siswa dalam belajar. Dalam menggunakan media gambar bergerak guru mempersiapkan penyajian media gambar bergerak berupa film bisu atau animasi, dengan memanfaatkan sarana dan prasarana yang ada dan menugaskan siswa menyiapkan peralatan yang digunakan dalam proses belajar mengajar. Guru menampilkan animasi menggunakan LCD dan proyektor, sehingga dapat dilihat jelas oleh semua siswa. Setelah ditampilkan, guru meminta para siswa untuk memberi komentar tentang animasi yang sudah dilihat. Kemudian siswa yang lainnya memberi tanggapan terhadap komentar tersebut. Setelah guru memaparkan materi pelajaran dengan perantara 'media kemudian guru meminta dengan cepat kepada siswa untuk menyebutkan 5 kosakata yang ada pada gambar animasi tersebut. Dengan seperti itu siswa akan cepat menanggapi pertanyaan dari guru. Setelah dilihat bahwa siswa sudah mampu mengetahui kosakata tersebut guru menganggap media ini sangat membantu siswa dalam pembelajaran. Tahap yang terakhir, guru menyampaikan kesimpulan materi pelajaran dan dilanjutkan dengan memberikan tugas hafalan kosakata kepada siswa untuk 'memperkaya penguasaan kosakata bahasa Arab.

Guru memberikan motivasi belajar baik di awal pembelajaran maupun saat berlangsung pembelajaran. Pemberian motivasi berupa reinforcement seperti sering mengucapkan kata-kata pintar, bagus, cemerlang untuk merespons jawaban siswa yang tepat. Guru juga memberikan hadiah-hadiah kecil bagi siswa yang mendapat perolehan nilai tinggi. Memberikan motivasi sederhana dan bentuk perhatian yang cukup terhadap siswa dengan segala potensi yang dimilikinya, karena banyak siswa yang kurangnya perhatian hal itu juga menyebabkan tidak adanya motivasi belajar. Oleh sebab itu guru mengajak untuk berpartisipasi aktif untuk lebih bergairah dan memperkaya proses interaksi antar potensi siswa dalam belajar. Selain itu, sebelum masuk 
pada materi pelajaran, guru sudah mempersiapkan aktivitas awal yang tidak membosankan bagi siswa, seperti bernyanyi, serta melakukan aktivitasaktivitas 'lain yang lebih menarik. Kegiatan terakhir dalam mengembangkan motivasi siswa adalah membuat kesimpulan dari kegiatan pembelajaran yang telah dilakukan. Dari kesimpulan ini akan dapat diketahui keefektifan siswa selama berlatih mengembangkan motivasi belajar.

Instrumen evaluasi merupakan langkah untuk mengukur kemampuan pemahaman siswa dalam penguasaan kosakata setelah menggunakan media gambar bergerak. Penguasaan kosakata tersebut yang nanti akan membuat siswa mampu melakukan komunikasi dengan bahasa. Semakin banyak kosakata yang dikuasai maka lebih memudahkan siswa menerima atau menyampaikan informasi yang lebih luas. Maka dari itu perlu diadakannya evaluasi pembelajaran guna mengetahui kemampuan penguasaan kosakata yang diperoleh siswa. Di antaranya dengan melakukan tes kosakata yaitu dengan menggunakan soal berbentuk objek pilihan ganda, dan ada pula yang berbentuk isian. Bentuk teks kosakata antara lain sinonim, antonim, memperagakan, definisi, melengkapi kalimat dan gambar. Untuk tes kosakata menggunakan kata-kata yang mudah dipahami, semua alternatif jawaban memiliki tingkat kesukaran berbeda. Pada langkah ini guru memberikan soal, yang muncul dari gambar tersebut, yaitu gambar animasi yang ditunjukkan oleh guru melalui proyektor. Setelah dilakukan tes dan guru sudah mengetahui hasil dari masing-masing siswa maka diketahui bahwa media sangat berperan, dan membantu dalam meningkatkan penguasaan kosakata bahasa Arab.

Keberhasilan pengajaran bahasa Arab dengan menggunakan media gambar bergerak tentu akan sangat membantu siswa dalam proses pembelajaran dengan baik demi tercapainya tujuan pembelajaran pada tingkat kemampuan dalam menguasai kosakata yang dimiliki oleh siswa, dan juga didukung dengan ketersediaan sarana dan prasarana. Dalam pelaksanaan pembelajaran dengan media gambar bergerak, sarana dan prasarana menggunakan gambar animasi, komputer, LCD, yang terdapat pada setiap kelas dan laboratorium. Agar keberhasilan dari kegiatan pembelajaran terlaksana dengan baik, maka harus diberi perlakukan pembelajaran dengan baik. Begitu juga pengajaran bahasa Arab dengan menggunakan media gambar bergerak tidak akan berhasil tanpa didukung dengan ketersediaan sarana dan prasarana. Dapat dipahami bahwa pentingnya sarana dan prasarana dalam pembelajaran merupakan bagian dari upaya mencapai tujuan pembelajaran secara umum dan tujuan secara khusus berlangsung dengan efektif. Pada proses pembelajaran keberadaan sarana dan prasarana sangat dibutuhkan dan akan mengalami kesulitan jika tanpa adanya sarana dan prasarana. 


\section{F. Kesimpulan}

Dari hasil tindakan menunjukkan bahwa guru telah melaksanakan seluruh aktivitas pembelajaran. Guru cukup baik dalam melaksanakan proses pembelajaran bila dilihat dari segi yang diamati, yaitu: (1) memulai proses pembelajaran (2) melaksanakan proses pembelajaran bahasa Arab sesuai dengan yang diharapkan dan sesuai dengan prosedurnya (3) menggunakan alat bantu/media pembelajaran sesuai dengan tujuan dan materi pembelajaran, (4) melaksanakan pembelajaran secara individual dan kelompok, (5) menanggapi pertanyaan dan respons dari siswa, (6) memberi penilaian hasil kerja siswa, (7) mengelola waktu pembelajaran. Proses pelaksanaan pembelajaran dalam rangka meningkatkan penguasaan kosakata bahasa Arab dengan menggunakan media gambar bergerak yang dilakukan oleh guru maupun siswa di MTs Darul A'mal menunjukkan bahwa adanya peningkatan. Penerapan pembelajaran bahasa Arab melalui penggunaan media gambar bergerak akan berdampak terhadap peran guru, khususnya cara pandang dan perlakuan terhadap siswa. Selain itu juga berdampak pada perencanaan dan pengembangan pembelajaran bahasa Arab yang meliputi pengelolaan kegiatan belajar, desain materi, metode pembelajaran serta penilaian. 


\section{Daftar Pustaka}

Afriyanti, Isma, Fadillah, dan Sukmawati. "Penggunaan Media Gambar Untuk Meningkatkan Aktivitas Dan Hasil Belajar Siswa Pada Mata Pelajaran Ilmu Pengetahuan Alam Di Sekolah Dasar Negeri." Jurnal Pendidikan Dan Pembelajaran Khatulistiwa 2, no. 2 (2013).

http://jurnal.untan.ac.id/index.php/jpdpb/article/view/1049.

Ardiyanti, Azisah, Irianti Bandu, dan Moses Usman. "Pembelajaran Kosakata

Bahasa Prancis Dengan Media Flashcard (Studi Kasus Pada Mahasiswa

Sastra Prancis)." Jurnal Ilmu Budaya 6, no. 1 (2018).

https://doi.org/10.34050/jib.v6i1.4327.

Astuti, Widi. "Berbagai Strategi Pembelajaran Kosa Kat Bahasa Arab." Journal Al-

Manar 5, no. 2 (2016).

https://journal.staimsyk.ac.id/index.php/almanar/article/view/38.

Febrisma, Nurliya. "Upaya Meningkatkan Kosakata Melalui Metode Bermain Peran Pada Anak Tunagrahita Ringan (PTK Kelas DV Di SLB Kartini Batam)." Jurnal Penelitian Pendidikan Khusus 2, no. 2 (2013).

http://ejournal.unp.ac.id/index.php/jupekhu/article/view/1150.

Hasnah, Sitti. "Pembelajaran Kosakata (Mufradat) Bahasa Arab Melalui Media Gambar Untuk Meningkatkan Minat Belajar Mahasiswa Pada Jurusan PAI Fakultas Tarbiyah IAIN Palu." Istiqra: Jurnal Hasil Penelitian 3, no. 1 (2015): 197-225. https://jurnal.iainpalu.ac.id/index.php/ist/article/view/217.

Hilmi, Hilmi. "Efektivitas Penggunaan Media Gambar Dalam Pembelajaran Bahasa

Arab." Lantanida Journal 4, no. 2 (2017): 128.

https://doi.org/10.22373/lj.v4i2.1885.

Ni'mah, Khoirotun. “Korelasi Penguasaan Kosakata Bahasa Arab Dengan

Kemampuan Berpidato Bahasa Arab Mahasiswa PBA UNISDA Lamongan."

DAR EL-ILMI : Jurnal Studi Keagamaan, Pendidikan Dan Humaniora 4, no. 1 (2017): 121. http://www.ejurnal.unisda.ac.id/index.php/dar/article/view/689.

Nurmadiah. "Media Pendidikan." Al-Afkar : Jurnal Keislaman \& Peradaban 5, no. 1 (2016): 43-62. https://doi.org/10.28944/afkar.v5i1.109.

Rudianto, Gaguk, dan Yessie Aldriani. "Pengajaran Kosakata Bagi Mahasiswa EFL Dengan Menggunakan Game." BASIS: Jurnal Bahasa Dan Sastra Inggris 5, no. 2 (2018): 53-62. https://doi.org/10.33884/basisupb.v5i2.770.

Sukiyasa, Kadek, dan Sukoco Sukoco. "Pengaruh Media Animasi Terhadap Hasil Belajar Dan Motivasi Belajar Siswa Materi Sistem Kelistrikan Otomotif." Jurnal Pendidikan Vokasi 3, no. 1 (2013). https://doi.org/10.21831/jpv.v3i1.1588.

Tafonao, Talizaro. "Peranan Media Pembelajaran Dalam Meningkatkan Minat Belajar Mahasiswa." Jurnal Komunikasi Pendidikan 2, no. 2 (2018): 103. https://doi.org/10.32585/jkp.v2i2.113. 
Yuswanti, Yuswanti. “Pengunaan Media Gambar Untuk Meningkatkan Hasil Belajar Siswa Pada Pembelajaran IPS Di Kelas IV SD PT. Lestari Tani Teladan (LTT) Kabupaten Donggala." Jurnal Kreatif Online 3, no. 4 (2014). http://jurnal.untad.ac.id/jurnal/index.php/JKTO/article/view/3077.

Zuhdy, Halimi. "Teknik Pengajaran Kosakata Bahasa Arab." Fakultas Humaniora UIN Maulana Malik Ibrahim Malang, 28 Oktober 2017. http://repository.uin-malang.ac.id/2138/. 
86 | Mariyatul Qibtiyah, Walfajri 